\title{
Evolving hunting practices in Gabon: lessons for community-based conservation interventions
}

\author{
Gretchen Walters $^{1,2,3}, \underline{\text { Judith Schleicher }}^{4,5}$ Olivier Hymas $^{1,6}$ and Lauren Coad $^{7,8}$
}

\begin{abstract}
Addressing today's environmental challenges is intimately linked to understanding and improving natural resource governance institutions. As a result conservation initiatives are increasingly realizing the importance of integrating local perspectives of land tenure arrangements, natural resource rights, and local beliefs into conservation approaches. However, current work has not sufficiently considered the dynamic nature of natural resource governance institutions over time and the potential implications for current conservation interventions. We therefore explored how and why hunting governance has changed since the precolonial period in two ethnic hunting communities in Gabon, Central Africa, integrating various ethnographic methods with resource-use mapping, and a historic literature review. In both communities, hunting governance has undergone significant changes since the precolonial period. A closed-access, lineage-based system of resource use with strict penalties for trespassing, has evolved into a more open-access system, in which the influence of customary governance systems, including magico-political aspects, has declined. These changes have occurred mainly in response to policies and governance structures put in place by the colonial government and postindependence, early state laws. This included a policy of merging villages, the introduction of more modern hunting techniques such as guns and wire cables, and a shift from community to government ownership of the land. Current governance structures are thus the product of a complex mixture of customary, colonial and state influences. These findings suggest that a historical perspective of resource governance, gained through indepth and long-term engagement with local communities, can provide important insights for community-based conservation approaches, such as helping to identify potential causes and perceptions of environmental change and to design more suitable conservation initiatives with local people.
\end{abstract}

Key Words: bushmeat; Gabon; historical ecology; hunting; natural resource governance

\section{INTRODUCTION}

Addressing today's conservation challenges is intimately linked to natural resource governance. Although natural resources are governed at multiple scales from the global to the local level, the focus of many conservation initiatives has been to improve natural resource governance locally, notably through community-based interventions.

Community-based conservation initiatives across Africa have, however, shown varying degrees of success (Brosius et al. 2005, Buzwani et al. 2007, U.S. Forest Service 2008, Roe et al. 2009, Child and Barnes 2010, Dressler et al. 2010, Shackleton et al. 2010). This is not least because conservation initiatives implemented at the local level are typically brought in by outsiders (Duffy 2006, Dressler et al. 2010), who fail to fully capture and appreciate the heterogeneity of local communities and the complexity of natural resource governance institutions (Leach et al. 1999, Ostrom and Cox 2010).

As a result there have been increasing calls for including perspectives from the social sciences into the largely natural science-dominated field of conservation (e.g., Mascia et al. 2003, Brosius 2006, Adams 2007) and for the incorporation of traditional ecological knowledge (Berkes 2004, Sola 2005, Leopold 2013) and ethnographic accounts (Pierotti and Wildcat 2000, West and Brockington 2006, Peterson et al. 2010). These perspectives can contribute toward gaining a richer understanding of communities' local beliefs and perspectives on land tenure arrangements and natural resource usage, access, and rights. A large number of studies have stressed that integrating these local perspectives into conservation initiatives is fundamental not only on ethical and moral grounds, but also for obtaining successful conservation outcomes (Soulé 1985, Campbell 2005, Drury et al. 2011, Schultz 2011, Lowe et al. 2013).

However, conservation initiatives often largely focus on presentday resource governance, rarely recognizing the dynamic nature of natural resource governance institutions over time and the potential implications for current conservation interventions (e.g., Bond et al. 2006). This happens despite the fact that studies outside the community-based natural resource management literature have shown that past resource governance (Toulmin et al. 2002), customary institutions (Kassibo 2002, Hinz 2003), and resourceuse cosmology (Krech 1999, Brink 2008) play important roles in how communities both previously and currently perceive and manage their resources. These issues are thus likely to influence current resource governance thinking and action.

In response to this gap in the conservation literature, we explore the dynamic nature of hunting governance in two communities in Gabon integrating various ethnographic methods with resource mapping and a historical literature review. We define hunting governance as the institutions and rules that determine how hunting is, or was, conducted in an area and how rights-holders, i.e., those with customary rights to the area, participate in these decisions (sensu Ostrom 2009). In particular, in this study we address the following questions: (1) How has hunting governance changed over time in the two communities? (2) Does historical hunting

\footnotetext{
${ }^{1}$ Human Ecology Research Group, Department of Anthropology, University College London, UK, ${ }^{2}$ Institut de Pharmacopée et de la Médecine Traditionelle, Herbier National, Libreville, Gabon, ${ }^{3}$ Missouri Botanical Garden, Saint Louis, Missouri, USA, ${ }^{4}$ Department of Geography, University of Cambridge, Downing Place, Cambridge CB2 3EN, UK, ${ }^{5}$ School of Geography and the Environment, University of Oxford, S Parks Road, Oxford OX1 3QY, UK, ${ }^{6}$ Institute of Zoology, Zoological Society of London, UK, ${ }^{7}$ Environmental Change Institute, School of Geography and the Environment, Oxford University, UK, ${ }^{8}$ Center for International Forestry Research, Bogor, Indonesia
} 
Table 1. Comparison of the Pouvi and Bateke peoples.

\begin{tabular}{|c|c|c|}
\hline & Pouvi & Bateke \\
\hline Case study & (Coad 2007, Schleicher 2010) & (Walters 2010) \\
\hline Principal vegetation & Forest with some agriculture & Savanna with riverine forest and some agriculture \\
\hline Main livelihoods & Subsistence and commercial agriculture and hunting & $\begin{array}{l}\text { Remittances from elite family members, pineapple wine } \\
\text { commerce, subsistence agriculture }\end{array}$ \\
\hline Access & $\begin{array}{l}\text { An unpaved road built in the } 1930 \text { s to } 1950 \text { s by the } \\
\text { colonial administration with forced labor; currently } \\
\text { maintained by logging companies and serviced by local } \\
\text { transportation }\end{array}$ & $\begin{array}{l}\text { An unmaintained sand track in place since the colonial } \\
\text { period and not serviced by local transportation }\end{array}$ \\
\hline Access to nearest town & 2 hours $(\sim 45 \mathrm{~km})$ away & 3 hours away \\
\hline Political representation & At several levels of administration including ministerial & At all levels of administrations including the Presidency \\
\hline Spirituality & $\begin{array}{l}\text { Branch of Bwiti, common among forest peoples of } \\
\text { Gabon }\end{array}$ & $\begin{array}{l}\text { Njobi, Mungala, Onkila; not shared by others in Gabon } \\
\text { but with the peoples of Congo }\end{array}$ \\
\hline $\begin{array}{l}\text { Literature on people } \\
\text { and area }\end{array}$ & $\begin{array}{l}\text { Very little literature available, mostly } \\
\text { from } \mathrm{PhD} \text { and } \mathrm{MSc} \text { studies }\end{array}$ & $\begin{array}{l}\text { Dating back to late } 1800 \text { s and early } 1900 \text { s with de } \\
\text { Brazza's explorations }\end{array}$ \\
\hline
\end{tabular}

governance influence current hunting governance in these communities? (3) How do community hunting practices vary between study sites? Based on the answers to these research questions, we then discuss how an understanding of the history of resource use governance can provide lessons for the design and implementation of community-based conservation interventions.

\section{STUDY SITES AND HISTORICAL BACKGROUND}

\section{Study sites}

We investigated the hunting governance of two Bantu-speaking communities in Gabon, a Central African country that is mostly covered in forest $(85 \%)$, with some savannas $(15 \%)$. The first focus population of this study are the Pouvi, a people who live in a forest environment and are thought to be some of the oldest inhabitants of Gabon (Klieman 1997). The second focus population are the Bateke, a people who live in a savanna environment. A summary of some of their key characteristics and differences can be found in Table 1.

The hunting, gathering, and agricultural Pouvi are found in the southern forested foothills of the Du Chaillu massif stretching between the cities of Koulamoutou, Mouila, and Banyati, within which approximately 4000 Pouvi live (Van der Veen 1991, 2003). The Bateke people occupy a series of savanna plateaus spanning more than $120,000 \mathrm{~km}^{2}$ across southeastern Gabon, central Republic of Congo, and southwestern Democratic Republic of Congo (Dupré and Pinçon 1997). The Bateke-Alima, a subgroup of the Bateke, have a local economy based on hunting, gathering, and agriculture. They are estimated to number approximately 15,745 people in Gabon (Linton 2008).

The Pouvi study was carried out by LC and JS in 2003 to 2005 and 2010 in two neighboring villages in the Ogooué-Lolo province, Dibouka $\left(1^{\circ} 19^{\prime} 07^{\prime \prime} \mathrm{S}, 12^{\circ} 12^{\prime} 54^{\prime \prime} \mathrm{E}\right)$ and Kouagna $\left(1^{\circ}\right.$ $\left.18^{\prime} 28^{\prime \prime} \mathrm{S}, 12^{\circ} 13^{\prime} 45^{\prime \prime} \mathrm{E}\right)$. Throughout the study period at least one author was living in Dibouka village. The Bateke study was carried out by GW from 2006 to 2010 in the villages of Ekouyi and Mboma (01 $\left.{ }^{\circ} 46^{\prime} 17^{\prime \prime} \mathrm{S}, 13^{\circ} 59^{\prime} 36^{\prime \prime} \mathrm{E}\right)$ and in the three neighboring villages of Kebiri, Saaye, and Lewu. GW lived full-time in Ekouyi 2006 to 2008 but had follow up visits in 2009, 2010, and 2011. GW and LC continue to maintain contact with some informants from both communities up to the present.

\section{Historical background}

In this study we describe hunting governance across the following three periods for both the Bateke and Pouvi study sites: precolonial (to the end of the 19th century), colonial (end of 19th century to independence from France in 1960), and postcolonial (1960 to present). Colonization began somewhere between 1839 and 1886, depending on geographical location (Aicardi de SaintPaul 1989, Gardinier and Yates 2006). From 1910 to 1958 Gabon was part of French Equatorial Africa (AEF) and in 1960 it gained independence.

Between 1950 and 1975 Gabon went from the least urbanized to the second most urbanized country in Africa (Wunder 2003), with $69 \%$ of the population now living in urban areas (United Nations 2005). The rural exodus is related to urban job opportunities causing young and middle-aged people to leave their villages in search of work.

\section{METHODS}

To provide insights into the dynamic nature of hunting governance in the Pouvi and Bateke study communities, we employed the following methods.

\section{Historical literature review}

Background information on AEF, Gabon, hunting practices, and the study sites, was collected from online libraries, such as Thomson Reuters's Web of Science, online archival records, and specialist libraries, such as the Archives Nationales d'Outre-mer, Aix-en-Provence, France.

\section{Participant observations}

In both studies long-term participant observation was used to better understand the hunting customs. The authors interacted with the local community in as many ways as possible. This included living in the villages and participating in communal activities such as gathering, fishing, hunting, agriculture, ceremonies, and cooking as well as helping in the local community with teaching, transport, and medical emergencies. Until this day contact has been maintained with these communities, with researchers and community members regularly calling each other to give updates on the affairs of the community and their lives. 


\section{Semistructured interviews and questionnaire survey}

To investigate how hunting governance and hunting practices have changed over time, in-depth semistructured interviews were conducted after a year of participatory observations. In the Pouvi site, we conducted 56 interviews in the two study villages with most hunters, while in the Bateke site formal (audio-recorded) semistructured interviews were conducted with 38 elders. In both study sites questions were based on the findings of participatory observations and informal discussions and were asked in an openended fashion to allow respondents to give additional information. In some cases follow-up interviews were carried out to capture more details on certain subjects and to clarify information. Interviews lasted between 0.5 to $2 \mathrm{~h}$ and in most cases they were carried out in French, with the assistance of local translators to help in cases where people did not speak French or preferred to answer in their local language. The interviews were audio recorded and in some cases filmed, and later transcribed and translated as needed with the help of a local assistant. All informants' names have been changed.

In the Bateke site, informal interviews occurred regularly and were recorded in notes, which were transferred into an Access database, resulting in approximately 800 entries. This work included interviews with most hunters in the five Bateke study villages.

Interviews were carried out as part of wider studies into resource use for both sites. A questionnaire survey of resource use was conducted with 122 residents in all five Bateke villages (Walters 2010, Walters et al. 2014), and a comprehensive survey of hunting returns was conducted in the two Pouvi villages (Coad et al. 2010, 2013).

\section{Focus groups}

During the study periods, focus groups and more informal discussions were carried out in French with the community on hunting practices and hunting governance. In some cases these were targeted at subsections of the community such as youth, women, hunters, and especially the elders to get their view on how hunting has changed in their lifetime. Present at these focus groups was a local translator and they were once again recorded to be later transcribed and where needed translated.

\section{Mapping}

Because of the differences in terrain between the two sites, different mapping methods were used in each. In the case of the Pouvi, who hunt in the forest where the view is limited, LC and JS followed the local hunters on their hunting trips and used a handheld GPS (60CSx, Garmin, Kansas City) to map the communities' land, gun hunting and trapping areas, as well as the location of hunting camps and old villages, that they came upon (Coad et al. 2010, 2013). In the Bateke case, because of the hilly, savanna landscape, it was possible to map hunting boundaries directly on topological maps with informants while standing on hilltops and viewing hunting territories from a distance. While walking through these landscapes with different informants, the hunting boundaries were discussed. From both of these datasets, maps were created and used in follow-up group discussions.

\section{Consideration for the community}

Throughout these studies care was taken to respect sacred areas and to not discuss culturally sensitive matters. Furthermore certain information was inaccessible to us because of gender barriers as well as initiation status. For instance, some ceremonies on land-fertility are male-only affairs, while other ceremonies are only accessible to people initiated into the tradition.

\section{RESULTS}

\section{Precolonial governance and hunting}

In the precolonial period in much of Central Africa, there were three levels of social organization: the house, village and district (Vansina 1990), the composition and location of which were flexible and changed according to region and historical period (Gray 2002). The house, a large household establishment, was the basic unit of social organization (Vansina 1990). The houses usually grouped together to form villages, or kin groups (Vansina 1990). The village would have had a territory in which the village members could hunt, gather, fish, etc. The defence of this territory was what united all the houses together. Finally the district consisted of several villages where strong links had been created because of trade and also defence of the territory; it had no head, but roused a "sense of ethnicity" (Vansina 1990:81). The governance of space was therefore dynamic, changing over time. Though the precolonial Atlantic trade started the introduction of guns into Gabon, there as early as the late 1800s in the Bateke study site, they only became common in the 1960s throughout Gabon (Bernault 1996).

\section{Pouvi}

Migration accounts of Pouvi related groups suggest that their ancestors moved to Gabon from Northern Congo before 2000 BC (Klieman 1997). The elderly Pouvi tell of a time prior to colonization when villages were typically small units, consisting of one or a few households from the same lineage (Ghebando or Bandou in Pouvi). Lineages were headed by a chief. Over time the composition and location of villages was dynamic and could change in response to natural resource availability and number of inhabitants, with villages moving location and smaller villages merging to form larger ones. A number of villages in the same landscape would form a district, and villages within a district would communicate with each other to form marriages or settle disputes.

Disputes between villages and lineages within a district, such as hunting accidents involving people from different villages, were resolved by the Missango (or Missanbo). He knew the histories of the different villages and lineages, and he was chosen for his ability to judge well. His title could be revoked by the village, through his death, or by resigning. Minor village disputes were handled by the lineage chiefs, rather than by the Missango.

The forest surrounding the Pouvi villages was divided into named hunting zones, typically delimited by rivers and hilltops. The zones belonged to individual lineages and within a lineage they were divided by households. They were therefore primarily governed by the lineage chief and then by the household head. In these zones only members of the household had exclusive access, resource extraction and management rights; only the members of the household could cross that part of the forest, drink the water in its rivers, fish and hunt within its boundaries, or impose hunting bans. The ownership of these forest zones was strictly enforced. Zones were protected from trespassers using sorcery, with magic 
boundaries for each zone created by an nganga (traditional healer). As a result, trespassers were believed to be punished by sorcery, causing illness, bad luck, e.g., lack of hunting success, or even death. If caught, trespassers could also be directly punished by the forest zone owners, including with slavery or death. Although these strict rules and their enforcement predated the lives of most of our respondents, older village members recalled vivid stories about the harsh consequences of trespassing: "Every bandou [lineage] has its forest. [...] There used to be fighting, if you find somebody over there [in your forest], two of you take him, stab him with the knife, stab him with the machete" (interview P42, 08 June 2010). Another informant noted the following: "The person who enters into the forest of another tribe, he will be imprisoned by the other tribe. They take him. [...] They keep him in the village. He works for them [...] as slave" (interview P45, 03 July 2010).

Our informants mentioned the use of different hunting techniques during the precolonial period, especially bow and poison arrows (called oté or ota), lance, and various types of traps. The principal trap was called ebai and consisted of a hole dug into the ground that was covered with branches and leaves. Hunters also wove cable out of raphia palms, which they would use in traps to catch animals by their limbs or neck.

\section{Bateke}

Prior to the colonial encounter, across the plateaus, resource use was administered by customary land chiefs (Vansina 1973, Bonnafé 1978, Dupré and Pinçon 1997). The Teke-Alima organized their lands into lineage-based hunting territories that were then grouped into village and then countries (Ebouli 2001), with each level having a chief (Vansina 1990). Territories constituted a magico-political space where the land chief maintained balance between the spiritual powers of the territory spirits (and ancestors) and the physical well-being, including food supply through hunting, of the constituent villages (Vansina 1973, Ebouli 2001). The Teke-Alima migrated into the study area in 1840 (Deschamps 1962) from the central Republic of Congo.

At this time, hunting was governed by the land chief with the major hunting events occurring as communal fire-drives. Territories that were scheduled to be burned were delimited into burn units and burned unit by unit in the mid-dry season (JulyAugust). The communal hunt included as many as 50 hunters and their nets, which when joined end to end, extended for kilometers (Dusseljé 1910). Fire specialists ran a lighting relay along the edge of the burn unit and animals were driven by the fire into the nets. Women would follow the flames, gathering small animals that had been killed (Walters et al. 2014).

Hunting governance was overseen by the land chief and included prehunt ceremonies; according to Samuel Onkadi, the land chief was the conduit through which the ancestors were speaking about the hunt (interview B5 with L. Makouka, 27 July 2008, Franceville). Every territory had their land-spirit and these were asked to give the hunt success using the olobo ritual, which requested protection from the ancestors and hunt safety and success (Le Bomin 2004). Another ritual, as demonstrated and described by land chief Kanini, was the Issami-issami dance, which would detail how the hunt would unfold (video recording B1, 1 July 2008, Malundu I). Other land fertility rituals included ambwongo, used to address problems in the territory, or requesting a blessing for an undertaking. The okoo ceremony is a ritual that is used prior to cultivation to avoid catastrophe and poor harvests but also to redress poor hunting success.

One of the ways in which hunting governance was assured was through fines and consequences for burning territories or hunting without permission. Other studies cite fines and consequences, including making peace with ancestral spirits, heavy fines in raphia cloths (Dupré 1994) and, for those who were not financially able, payment in the form of slavery or the loss of a daughter in marriage (Mouayini Opou 2005). When we asked villagers who had participated in the land chief system to list the fines and consequences, they remembered sacrifices of goats, chickens, and red wine to ancestors but also slavery, forced marriage, and illness. Fire-setter J-M. Andza reported one case from the study site where a woman had been offered as payment for a hunting accident in a territory (interview B10, 19 November 2007, Leconi). In comparison, the theft of a goat or a gun in 1929, in an area adjacent to the Bateke, incurred a fine of only 20-30 raphia cloths (Badier 1929). This disparity in fine severity demonstrates the seriousness of pyro-crimes, which resulted in the loss of women and bride-wealth. Unauthorized burning also had spiritual consequences, manifested by sickness or death and required giving penance to the ancestors. Unauthorized burning was a serious offense because it was considered to be a transgression against the ancestors of the domain. In one example given by Pierre Anza (interview B11, 20 August 2008, Kebiri) in which he hypothesized about unauthorized fire burning in his lands, he indicated that members of the offending territory would be required to make amends by offering wine and money. He would take the wine, call the people of the territory, and enter into the territory olebe, a structure that houses the land spirit, where he would pour out the wine and ask for pardon in front of the territory spirit.

\section{Colonial governance and hunting}

The colonial government perceived the migratory nature of the villages by many ethnicities as evidence of lack of "attachment to land" (Kinata 2001:44), promoting colonial laws that resulted in centralized land tenure with the state. In the 1900s, colonial policies resulted in mapping ethnicities and territories to create spaces and people to rule. This mapping process denied existing African ideas of territoriality and cultural identity, and with the boundaries demarcated by the French poorly matching Gabon's fluid notions of how people governed space (Gray 2002, Reed and Barnes 2003): it led to regroupement.

The regroupement policy forced villages to regroup into settlements near roads to ensure access to health and education and to create a controllable work force for the state (CoqueryVidrovitch 1972). Resettlement efforts occurred between 1910 and the 1960s. Over this period, 4111 villages were reduced to 770 villages, which were aligned along roads (Pourtier 1989a). The regroupement policy forced some ethnic groups to migrate into the customary lands of other groups, creating assemblages of villages that would not have chosen to do so otherwise, and so, causing resource-use conflicts (Jean 1975). In some cases, people volunteered to move to improve their access to education and health services, but in other cases, people refused and instead, fled into the forest (Hymas, in press). 
The French also developed a system of state-appointed chiefs including village chiefs and canton chiefs through which they ruled and collected taxes; this was a top-down approach whereby powers from chiefs could be removed and canton areas combined at the whim of an administrator (Métégué N'Nah 1981, NzeNguema 1998, Yates 1998). The colonial government further introduced many hunting, fire-setting, and land tenure laws that significantly impacted historical and present resource use. As early as 1899 , the French established legal rights over forest perceived to be unoccupied in the AEF (Jaffré 2003). Hunting laws continually evolved, reducing customary controls over time and centralizing hunting authority at the state level. Between 1904 and 1956, laws began to control hunting-related fires, species quotas, hunting zones, and restricting hunting techniques (Walters, in press).

\section{Pouvi}

The governance of the Pouvi's customary territory, including their hunting zones, was influenced by colonization, in particular through the forced relocation of villages under the regroupement policy. Village members recalled that the current position of Dibouka, and the lineages represented within it, was the result of multiple merging and relocation of villages, in response to both voluntary migration and forced regroupement. GPS mapping of old Pouvi villages identified at least 28 old village sites surrounding Dibouka and Kouagna (Fig. 1). These villages were abandoned as they relocated and/or merged with others (Fig. 2). Focus group discussions revealed that four lineages previously existed in the current hunting territory of Dibouka: the Sima, Moussonga, Ndzobe, and Mouivo. Before regroupement some villages of these lineages had already slowly joined together over time to form larger villages (Fig. 2). One of the village chiefs recounted that one village merging had occurred due to a marriage between two lineages, moving to a piece of flat land between the two village territories. Although respondents did not recall approximate dates for most of the village relocations nor whether they occurred before or during regroupement, interviews revealed that Dibouka 1, which existed by the 1930s, was moved as a result of regroupement across the Yahoo River to form Dibouka 2 and was later relocated to Dibouka's current location.

The merging of several lineages into one village, and in particular the forced relocation of villages under regroupement, started the process of breaking down the Pouvi's customary governance of the hunting zones. In addition, the colonial government set up a new administrative and governance structure, which included appointing a chief for each village, and established new national hunting regulations. The establishment of these new authorities further weakened the customary governance structure, based primarily on lineages and household heads, and consequently eroded the use of household hunting territories. Our informants recounted that as villages comprising different lineages merged into Dibouka 1, people started entering, and even hunting in the forest zones of other lineages of the same village without facing the previously harsh punishments. Most informants related these changes to the influence of colonial regroupement and/or nationalization of resource governance, as related by one informant: "It was before the regroupement that it was like this [the strict enforcement of hunting zones]. When the white came
Fig. 1. Diagram showing the approximate size and shape of the 91 hunting zones mapped in Dibouka and Kouagna, two Pouvi villages. Hunting zone size and shape was approximated by the GPS location of 10,700 traps where hunting zone name was known. Further hunting zones are likely to exist in the areas that were not used by hunters during the two study times. For Dibouka hunting zones, hunters were presented with a list of zone names (in alphabetical order) and asked to identify the lineages to which the zone belonged. Identified lineages for each of the hunting zones are represented in the four colours. Old village locations are represented as black stars.

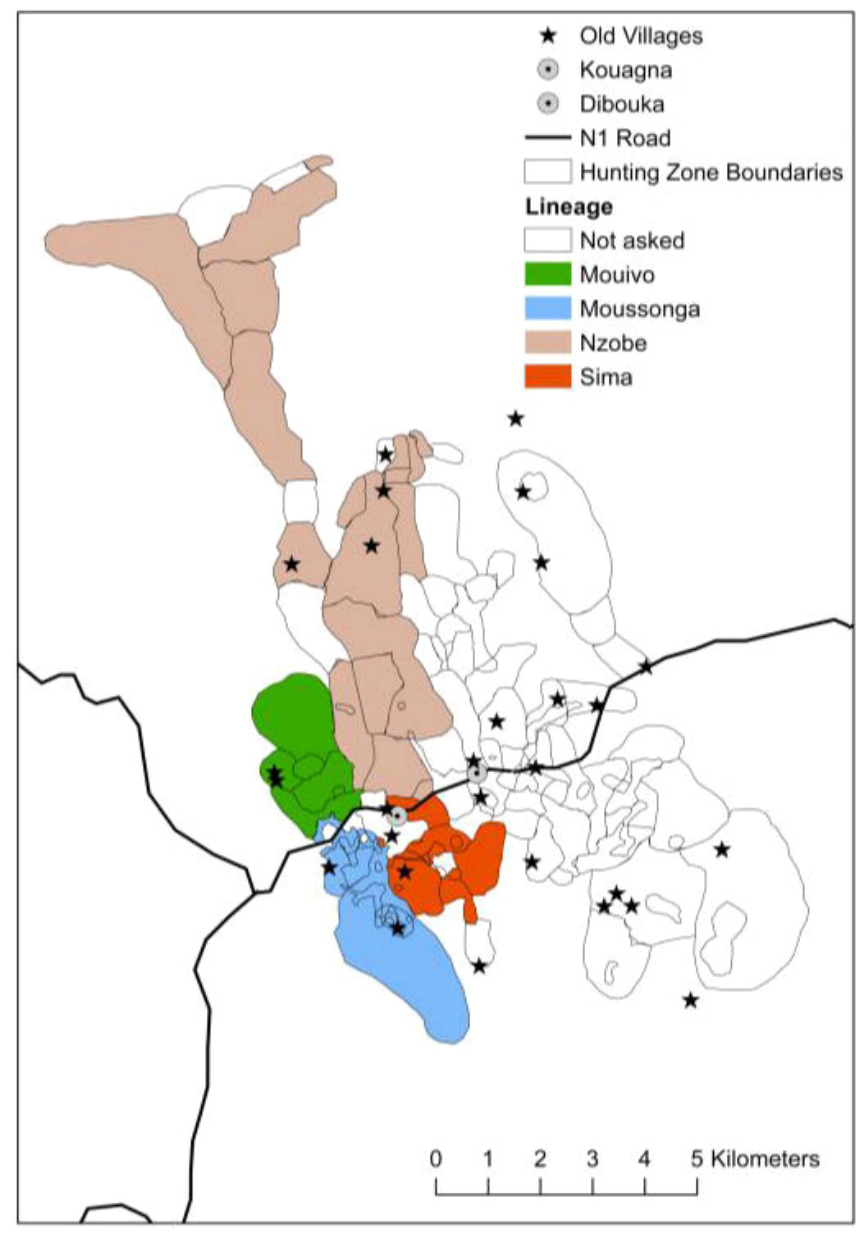

they said no, it's not like you have it there, the forest is for everybody" (interview P29, 2005). Another informant noted the following:

Before [...] there were zones, where it was strictly forbidden to the public [...], therefore every family had their territory to hunt, their forest territory, territory to fish. [...] [When I was young], it was still like this [...]. The forest, as it is today, everyone goes there because of the white; [...] they said [...], 'the animals and the forest are now for the government. The one, who will cause 
problems, will go to prison.' [...] It has really changed after Independence, when it really changed. When the French were there, it was almost still the same, [...] there were still territories, which were defended. But it is really after Independence, [...] that this was really abolished. [... Now] somebody from Libreville [Gabon's capital] comes here, kills animals. It [the forest] is not defended [by the people in the village...]. Because now the forest is the administration, it is not defended as before. [...The change] was gradual (interview P55, 22 July 2010).

However, some respondents suggested that the voluntary regrouping of villages, prior to colonial regroupement policies, had already begun to weaken the use of hunting zones:

When the three villages were regrouped the other side of the Yahoo, each tribe had their parcels of land, but already people were going into the [hunting] zones of others. There were no longer any 'defences.' People from Moughabo could go into Mabembe to hunt, or Mangonde. If someone went to put down traps in Mabembe and went to kill an animal, we would not have said 'no, don't go over there.' They were already 'sociale. 'The law was stricter in the small villages. When they started regrouping, in their own rhythm, they started eliminating the rules and going into the zones of others, before the arrival of the administration. (focus group P2, August 2010)

Fig. 2. Diagram showing how the four main lineages from Dibouka (a Pouvi village) regrouped. Dark grey circles represent the four lineages and the different points at which they merged with other lineages. Light grey circles represent old villages, with names where known. The present location of Dibouka is represented by the white circle.

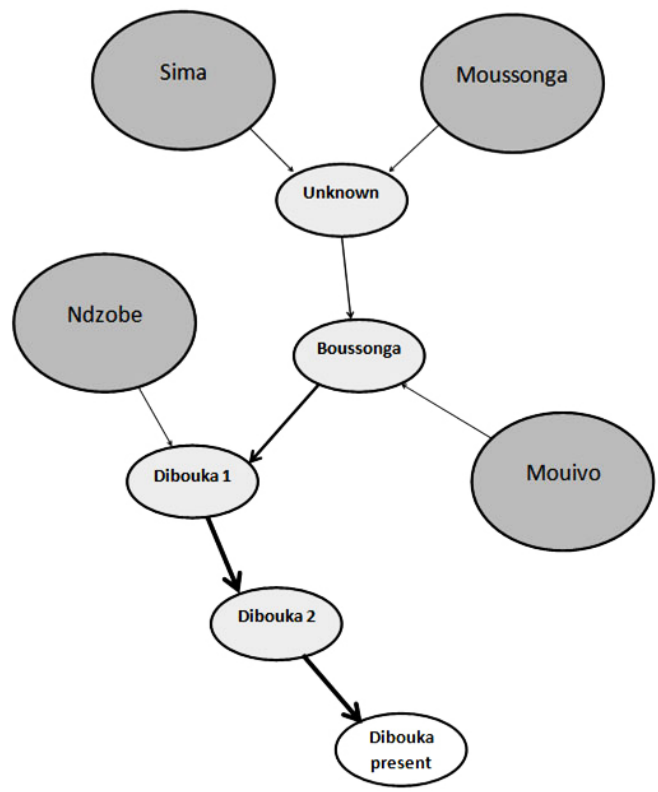

Bateke

For the Bateke, the reorganization of their territory began with de Brazza's explorations where he became an "inventor of space" (Pourtier 1989b:83, Gray 2002:104), with his mapping and treaties that opened their and other's territories to colonization. The French established the first canton, an administrative unit not unlike the territory, in 1920 (Gray 2002).

According to Andza, "Each savanna has its protector" (interview B11, 20 August 2008, Kebiri) or land chief. Around EkouyiMboma, there were approximately 10 hunting territories. These territories occupied all lands, leaving nothing vacant.

Regroupement policy had an impact on hunting governance in the study area. Regroupement occurred in the 1950s-1960s in the area and displaced the people from their territories. When Land Chief Kanini recounted the regroupement of his village from his savanna territory to a forested area, he indicated that the forest people told them "Go back home to your territories" (interview B12, 1 July 2008, Malundu I). The forest people initially forbade livelihood activities by the Bateke immigrants. For many years, these Bateke went back to their territory to conduct hunting and gathering activities, traditions they have since abandoned because they now rely almost exclusively on forest resources. In the study site, the Teke-Alima people were regrouped with the Bakaningui of the nearby forest. When the Bakaningui forest people immigrated to the savanna area of Ekouyi-Mbouma, Bakaningui Chief Yua recounted that although they still returned to their former forest areas to hunt, they exchanged hunting techniques. However, both groups maintained distinct hunting territories. He further explained, "When we wanted to hunt, we returned to the forest around our old village; they [the Teke-Alima of Mbouma] would go to the savanna. But since we have been regrouped, we hunt together in the forest, with the people of the savanna" (interview B23, 30 September 2007, Ekouyi). Chief Nturi of Mbouma indicated that hunting territories in the savanna are recognized by all and it was known that those from the forest of Ekouyi did not have territories in the savanna, "the way that the Kimi territory is our territory, the Kankuru territory is ours; Ekouyi doesn't have territories here" (informal interview, Kele la Kalami, 12 July 2007).

\section{Postcolonial: 1960 to present}

The postcolonial laws changed many aspects of natural resource governance. When Gabon gained independence, many laws from the AEF were transferred into Gabon's state law. In addition, just after independence, a series of laws transferred most land rights to the government, revoking all customary land ownership (République Gabonaise 1963). All territory outside of village jurisdiction fell under state law; however, a few years later, villages were able to control and exploit lands for subsistence up to five kilometers from the village center. Gabon's present day forestry code forbids hunting without a permit, in closed season, in protected areas, from a car or plane, at night, with nets, fire or pits, and with metallic cable traps. In 1994, a decree protected threatened species in Gabon such as the endangered Grimm's Duiker, the main target of the Bateke fire drive. According to the present-day forestry code, fire-drives are forbidden.

\section{Pouvi}

The current governance structure in the two villages was put in place by the state, with one regroupement chief for the two villages 
(based in Dibouka), and one village chief in each village. Lineage chiefs were no longer reported to be in existence, although there were quartier chiefs for different sections of the village, which may have in some cases loosely mapped the old lineages. The villages no longer consulted a Missambo for intervillage disputes; these were regulated by the village chiefs, or the canton chief for more serious issues, following the colonial and now national governance structure. The last Nganga (traditional healer, with the power to protect hunting boundaries using sorcery) in Dibouka and Kouagna was dying during our field period in 2010, and informants said that he would not be replaced because no-one else had the knowledge and powers to be an Nganga.

During our field visits in 2005 and in 2010, the importance of traditional animist beliefs (Bwiti) were in evidence, although village members preferred not to discuss these beliefs with us because of our gender and because we were not initiated. However, during 2004-2005 LC observed the use of the Pouvi Ndzergho (leopard spirit group) to regulate village disputes, with group members calling upon the spirits to identify and punish a village thief. Other ceremonies were conducted approximately every 2-3 months, which noninitiates were not able to attend. Certain areas of the forest were also used for initiation into male and female Pouvi initiate groups, and could not be entered by noninitiates. It therefore seems that traditional beliefs are still active, and an important aspect of village life.

Over time the customary land tenure arrangements and hunting rules have nearly disappeared, although the names of the forest zones and the knowledge about which lineage they belonged to still persist. Villagers continue to use the names, for example to indicate where in the forest they have been as well as where their hunting areas and agricultural plantations are located. However, the zone limits are no longer enforced, and the previously harsh punishments for trespassing are no longer applied. During the study period any member of the two villages, comprising several lineages, was allowed to access and cross any part of the forests surrounding the villages, with the exception of sacred areas used for male and female initiation ceremonies. Most hunters believed that the same applied to hunting, meaning that all members of the village were free to hunt where they wished as long as they were familiar with the forest and did not place their traps too close to traps already laid down by another hunter because this might diminish his catch rate. In practice however, the two neighboring villages maintained distinct village hunting areas. Hunters often hunted in their lineage's hunting zone where their older relatives had hunted previously because this is where they had typically learned to hunt from family members, and therefore where they knew the forest best.

The current rules seemed less clearly defined concerning whether outsiders could hunt in the forest around the Pouvi villages. Whereas some hunters told us that only villagers and their relatives could hunt in the surrounding forests, others felt that anybody, including strangers, could hunt there. They would simply need to ask permission from the head of the village or the head of the regroupement, and then accompany village hunters into the forest to become familiar with the forest. Some village members thought that the village head would readily grant such permission to outsiders, although one village head himself said that he would only grant the hunting permission to outsiders in very exceptional circumstances. A recent example of granting hunting rights to an outsider can be seen in the case of the pharmacist, an Nzebi (a neighboring ethnic group in Gabon), who was seconded to Dibouka for the government health program. He was given permission by the chief of the village to hunt in the village territory, in the forest zone where another Nzebi, who had married a Pouvi woman in the village, was already hunting.

A reason given repeatedly for the disintegration of the customary hunting rules was that with the colonial administration and following independence villagers in Dibouka and Kouagna felt that they have lost their customary, communal (lineage or familybased) land tenure rights of the forest surrounding the villages because of state "ownership" of the forest. Many informants believed that the "forest belongs to the state" (interview P46, 8 July 2010). "It's the state that benefits from the forest. It's the state that eats there now" (interview P22, 2005).

Over time hunters have also adopted more modern hunting technologies, no longer using bow and arrows, lances, or the labor intensive ebai traps. The holes in the ground that remain of the ebai traps can still be found throughout the forest around the villages, indicating their relatively recent disappearance. Raphia cable has been replaced by wire cable, which started to become common in the study villages in the 1960s and 1970s along with guns, introduced to Gabon by the colonial government. Over the study period between 2004 and 2010, the number of hunters using guns increased compared to hunters laying traps to catch animals. The overall number of hunters active in the village decreased however over that period because village men moved out of the villages to seek employment opportunities (Coad et al. 2013). According to informants the switch to more modern hunting techniques has contributed to increased hunting off-take from the forest, an increment in the sale of bushmeat for local town markets, and a decline in local wildlife populations.

Bateke

According to our informants, the last fire-drives were conducted in the late 1960s. By then, Bateke hunting governance had changed as customary control over lands and fire was reduced through the introduction and enforcement of state laws, guns became common, and people immigrated to cities, leaving very little in place that resembled the former system (Walters, in press). Today, hunting fires burn in nearly every season; these fires are no longer actively used to drive game into nets, rather, fire is used as a passive tool, used to create sites of young grass to which grazing game is attracted. This nearly continuous firing differs greatly from the annual dry-season fire regime maintained in the land chief era only 50 years ago (Walters 2012, Walters et al. 2014).

Whereas the past fire regime used a net-based, communal hunting method, today's system uses guns and is almost entirely lacking in social organization. Although people today remember past burning as almost exclusively linked to hunting and gathering, many today indicated that people burn for pleasure. Some cited a lack of respect, stating particularly that the youth burned in disorderly fashions. According to Ndigi, "Today, people burn in disorder. There are no more limits and there is no one who can give orders of this kind. These people do what they want" (survey 8 June 2007, Mboma, translated by S. Touladjan). As a result, today's hunting fires cross domain borders without consequence, although hunting territories remain recognized (Fig. 3). 
Fig. 3. Representative map of (a) former and (b) current burning patterns in Bateke villages. Pre-regroupement, each village had delimited burn units, which were smaller and surrounded the village fields, with a strict communal burning schedule authorized by the village land chiefs. In the present day, delimited burn units are no longer enforced, and unregulated burning of the savanna crosses the old delimited burn unit boundaries and village hunting boundaries.
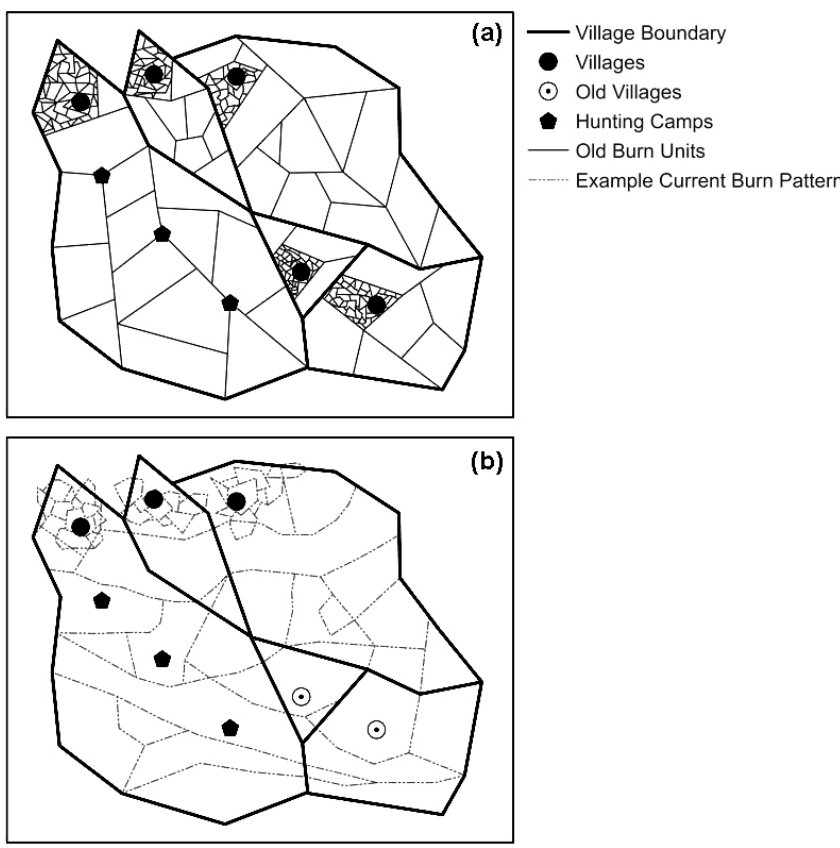

Despite the unregulated hunting fires in the territories, the people of Mboma still hunt there. Informants indicated that although they did not have to ask for permission to hunt in other territories they often were accompanied by members of the territory's lineage. Chief Nturi indicated that today, hunters from neighboring villages (and lineages) hunt in his territory (informal interview, Kele la Kalami, 12 July 2007). Although the people of Mboma continue to hunt in their savanna territories, those of Ekouyi stay in their forest ones, with each lineage having a named forest. Nonetheless, each lineage largely continues to hunt in their historic territories. Sebastien Mvula indicated that although these groups hunt together, they always "kept their inherited ways of hunting" (informal interview, 19 November 2007, Leconi). Nonetheless, $88 \%$ of the survey respondents indicated that there are no penalties for savanna burning without authorization today and despite most people knowing the word for a land chief (ngantse), most youth surveyed did not understand his historic function.

However, there are informal ways in which hunting governance occurs. Outsiders are not welcome to hunt in Bateke hunting grounds, particularly the urban, commercial hunters who access the area without first consulting the communities. During the study period, Kibiri village organized itself against these hunters by setting nail traps when the cars of urban hunters passed through their village at night. Other villages near the study site were conducting self-authorized road blocks to search cars that might contain quantities of bushmeat from their territory (Walters et al. 2014).

Despite these changes in present day use, there are still remnants of the old system. Even if hunting fires are no longer controlled by land chiefs, domain limits are generally known, despite fires crossing these boundaries. Although no authorizations are sought for hunting and no compensation is given for territory problems, resource use is still governed by land fertility rituals.

During the study period, in periods of ecological imbalance, villagers blamed negligence of both ceremonies and sacred places. For example, manioc fields were being ravaged by bush pigs while caterpillar and beetle gathering had not been productive. Although some believe that fault lay in neglecting the territory spirit, others blamed the general disregard for territory rules. To make amends with the ancestors of his territory, Mbia thought that it might be best to bring water from another sacred wood to restore theirs, along with sacrifices of kola and red wine. A ritualized plantation was made as another effort to correct land fertility problems (personal observation, November 2011). However, these practices are becoming rare in some villages and are regular in others. During fieldwork, the people of Ekouyi annually organized an okoo ceremony, however Mboma had only practiced their okoo once.

Regular lighting of the fetish fire in Kankuru territory still occurs every few months and some ceremonies, like Ambwongo are still practiced there. However, the olobo, according to Antoine Mbia, was a song that only one person of Kankuru Domain still mastered in 2014

\section{DISCUSSION}

Our comparative study shows that both the Pouvi and the Bateke hunting governance systems have undergone profound changes since the precolonial period, emphasizing the dynamic nature of hunting traditions and governance institutions. The hunting governance as practiced today is a product of this history, being influenced by both the precolonial customary governance and the changes that the hunting systems have undergone since colonial rule and independence. Similarly drastic governance changes in response to colonial rule have been documented in other parts of Africa (Laris and Wardell 2006), where many of the past systems were present only a few decades ago, and much of the traditional practices have been further eroded in the face of market forces and modern practices (Marks 1979, Forbes et al. 2014).

\section{History as a common factor}

It is clear that for both study groups, governance of land use and of hunting was highly impacted by colonial and postindependence rule, resulting in a shift from closed-access, community hunting governance toward increasingly open-access hunting systems. Prior to European contact customary chiefs were responsible for regulating societal and environmental problems. Following colonization, the legitimacy of these customary chiefs came under question because of the application of a new colonial administrative structure, and customary rule became difficult to maintain within the colonial realm (Nuesiri 2014). Although some customary rituals are retained, especially in the case of the Bateke, 
Table 2. Comparison of past and current hunting governance in the Bateke and Pouvi case study sites.

\begin{tabular}{|c|c|c|}
\hline & Pouvi & Bateke \\
\hline \multicolumn{3}{|l|}{ Past hunting governance } \\
\hline Governance structure & $\begin{array}{l}\text { Forest zones governed by lineage head and then } \\
\text { household head. Hunting generally individual }\end{array}$ & $\begin{array}{l}\text { Forest zones governed by land chiefs at the lineage, } \\
\text { village, and country level. Hunting generally } \\
\text { communal }\end{array}$ \\
\hline Hunting beliefs & $\begin{array}{l}\text { Information not available to noninitiated } \\
\text { interviewees }\end{array}$ & $\begin{array}{l}\text { Every zone had its land spirit, and prehunt rituals } \\
\text { ensured hunting success. }\end{array}$ \\
\hline Regulation through hunting zones & $\begin{array}{l}\text { Hunting zone boundaries enforced by sorcery and/ } \\
\text { or direct penalties, including bad luck, slavery, and } \\
\text { death }\end{array}$ & $\begin{array}{l}\text { Heavy fines/slavery for burning territories or } \\
\text { hunting without permission, spiritual } \\
\text { consequences manifested by sickness or death and } \\
\text { required giving penance to the ancestors. }\end{array}$ \\
\hline Division of space & Hunting zones approximately 1 to $2 \mathrm{~km}^{2}$ & $\begin{array}{l}\text { Hunting and burn zones approximately } 10 \text { to } 150 \\
\mathrm{~km}^{2}\end{array}$ \\
\hline \multicolumn{3}{|l|}{ Current hunting governance } \\
\hline Governance structure & $\begin{array}{l}\text { Village chiefs (appointed by national government); } \\
\text { hunting no longer controlled by lineage chiefs; } \\
\text { hunting generally individual }\end{array}$ & $\begin{array}{l}\text { Village chiefs (appointed by national government); } \\
\text { fires no longer controlled by land chiefs; hunting } \\
\text { generally individual }\end{array}$ \\
\hline Regulation through hunting zones & $\begin{array}{l}\text { Territories known but not enforced; no penalties } \\
\text { currently used }\end{array}$ & $\begin{array}{l}\text { Territories known but not enforced; no penalties } \\
\text { currently used }\end{array}$ \\
\hline Hunting beliefs & $\begin{array}{l}\text { Observed to still be active among older hunters } \\
\text { and village members, but not openly discussed } \\
\text { with noninitiated people }\end{array}$ & $\begin{array}{l}\text { Still active, but reduced in importance and not } \\
\text { openly discussed with noninitiated people }\end{array}$ \\
\hline
\end{tabular}

the old magico-political systems of resource governance in both case studies have mainly fallen out of use today.

In the colonial era, a lack of understanding of the social context led to a mismatch between European and African land cultures and how this related to geographical space (Bohannan 1963). Although the European administrators tried to define ethnic territories based on maps, the African groups of southern Gabon defined their space through matrilineal clan relationships, creating social territories that were relatively independent of space (Gray 2002). The Pouvi and Bateke customary chiefs regulated hunting primarily through governing space, using hunting territories and burn units; the colonial and national administration regulated hunting primarily through restrictions on hunting methods, seasons, and species. The erosion of traditional hunting governance through the use of space was further influenced by the colonial policy of regroupement. In the Bateke villages informants noted that regroupement reduced their ability to organize hunting in their customary areas and also indicated that the rural exodus removed the age group of men from their villages who would have been trained in the communal hunting practices, causing a break down in the transmission of hunting techniques (Walters, in press). In the Pouvi villages informants noted that the merging of villages and lineages, in combination with the application of colonial and postindependence laws pertaining to state land ownership, eroded the influence and implementation of the hunting zone boundaries.

For both study sites, the introduction of new hunting methods also had a profound effect on the hunting culture. In the Bateke Plateaux, the procurement of guns led to a move from communal net hunting to individual hunting using guns. Commercialized illegal hunting of bushmeat is the largest conservation problem for the nearby Parc National des Plateaux Bateke (ANPN 2013) where declining wildlife densities and intense hunting pressures have been reported (Bout 2006). Today's modernized hunting techniques (Gami 2003) and changes in the customary governance over hunting territories and fire use have likely contributed to this decline (Walters, in press). For the Pouvi, pit traps and raphia cable snares have been replaced with gun hunting and wire cable snares, and these new, more efficient methods have increased the sale of bushmeat to local town markets and were perceived to have contributed to the decline in wildlife populations.

\section{Culture and environment as differentiating factors}

In comparing these case studies, it is clear that there are differences between the way local people managed and continue to manage their lands, as illustrated in Table 2. The Bateke people have a more hierarchical customary governance system including supreme land chiefs, land chiefs, and lineage chiefs that each controlled large areas in the savanna and were responsible for hunting governance. In the study site, the regoupement of forest and savanna peoples together in the main study village resulted in a sharing of hunting traditions, but a maintenance of separate hunting zones. Although the land chief system no longer fully functions and was largely eroded during colonial and early Gabonese state rule, with the state attempting to control hunting seasons, species, and offtake, there are still land fertility practices that influence beliefs in animal abundance and scarcity. The Pouvi, by contrast, have a much less hierarchical customary governance system and although they have maintained the names of their lineage-based hunting zones, the access to these zones is no longer restricted to the lineages and their hunting beliefs appear to be much reduced.

\section{Lessons for the design and implementation of community-based conservation interventions}

A historical analysis of how and why natural resource governance has changed over time can help to understand drivers of environmental degradation and wildlife declines. Poor resource management by local communities has sometimes wrongly been identified as the cause of overhunting and wildlife declines (Parks 1992, Leach and Mearns 1996). However, it may in fact be the 
erosion of local systems of hunting governance that leads to unsustainable hunting practices over time. In this example, the customary closed-access, communally governed hunting systems of the two study groups have shifted to more open-access systems of bushmeat extraction in response to laws and policies put in place by the colonial and Gabonese governments. This shift has been attributed as having contributed to local wildlife declines. By helping to identify causes of environmental degradation, the historical perspective can therefore provide the critical first step toward addressing them and contribute toward designing more effective conservation interventions.

An understanding of the history of the governance of natural resource use can help to design conservation interventions that do not clash with existing and remnant governance structures. In addition, knowledge of past responses to change can provide insights into how the existing practices might respond to new interventions. This is particularly important because conservation interventions will exist on top of, or in parallel to, existing governance structures, which as highlighted in this study are the result of a complex mixture of historical factors. Although across much of Central Africa customary governance system were present only a few decades ago (Forbes et al. 2014), these past governance systems operate in a very different setting today, and cannot be considered as a panacea for natural resource management issues (Cordell 1993). Nevertheless, knowledge of these systems can still have important impacts on conservation planning and project success. For instance in the Pouvi site, a project aiming to regulate hunting through the use of spatial hunting zones would need an understanding of how the forest was, and the extent to which it still is divided and enforced by lineages and what the implications of strengthening or reestablishing governance might be. Where these systems involve complex spiritual beliefs, potential unintended consequences of re-establishing customary spatial hunting zones need to be considered carefully.

In another case from Central Gabon, conservation organizations sought to prioritize work with Pygmy groups, assuming that they had the earliest claims to the forest in a conservation area; in reality, after careful documentation of the migration routes and oral histories in the area and its peoples, it was shown that Bantu groups had been there longer. This assumption of history by outsiders caused tension among the Pygmy and Bantu groups with which the conservation organizations were working (Hymas, in press).

To obtain detailed accounts of historical and current resource use and governance requires in-depth and long-term engagement with communities and could be served by a higher level of collaboration between social and biological conservation scientists (West and Brockington 2006). Although in Central Africa much conservation effort is spent conducting participatory mapping exercises to contribute to conservation, and many lessons have been learned (Yanggen et al. 2010), most projects employ rapid assessments with communities, resulting in an incomplete picture of community resource governance that can negatively impact project success. In an effort to conduct a 4-day participatory mapping in one of the Bateke study villages, one NGO created a "participatory" map that significantly underestimated the area of actively used hunting zones. Despite sporadic engagement with the community on a variety of topics over the past decade, the NGO had not consistently engaged in understanding hunting practices or zoning and how people use the landscape today (Nse Esseng 2009). Similarly in the Democratic Republic of Congo, work with communities by large conservation NGOs and as part of a regional donor-lead conservation initiative included an effort to map landscapes that resulted in maps produced without full consultation of rightsholders and stakeholders. This has left those communities angered by the lack of adequate engagement and is perceived as potentially threatening their claims for tenure and resource use (Oyono and Ntungila-Nkama 2015).

In contrast, understanding of historical natural resource governance through long-term engagement can help gain trust with communities and provide the basis for cultural understanding. In the Bateke study site, hunting had been so stigmatized by conservation agencies that at first some informants were reluctant to discuss hunting practices during this study. Toward the end of the main fieldwork period, local people began to see the researchers as advocates for their practices. Building relationships with communities requires reducing the social distance with them and focusing on increased cultural understandings. In line with this, the conservation community is increasingly recognizing the importance of understanding the cultural context of resource governance to help design successful community conservation projects (Waylen et al. 2010), including work on cultural taboos against hunting gorillas (Etiendem et al. 2011), supernatural influences on hunting practices (Pagezy 2006, Sasaoka and Laumonier 2012), and the role of secret societies (Martín-Martín 2011). Increased cultural understanding and trust building ultimately benefits the community, conservation organizations, and the government's land agencies to build better collaborative relationships, increasing the likelihood for designing successful conservation projects (Stern 2010).

However, more than cultural awareness is needed: understanding the natural resource governance of the community with which an organization is engaged can help place ideas of abundance and scarcity into contexts. At the Bateke site, local people believed that natural resource depletion was due to the negligence of sacred sites whereas conservationists attributed it to overhunting. Recognizing and discussing these diverging views can help advance both concerns about reduced animal numbers, even if there is not an agreement on the cause.

Finally, conservation organizations need to acknowledge and take into account the highly heterogeneous nature of communities in Central Africa and beyond (Blom 2010). As the two Gabonese case study communities clearly highlight, the traditional and current hunting practices and governance of the Pouvi and Bateke are different in many ways, likely requiring varying conservation approaches. Conservation organizations therefore should be careful not to base project design on assumptions of how local people use or think about resources and space gleaned from studies of other communities. Assumptions from the international to national or national to subnational levels should be tested before being used to design interventions. Conservation approaches should be adapted to each community with which they engage, rather than having a one-size-fits-all approach (Giles-Vernick 2002). Doing otherwise risks a repetition of the 
colonial practices described here, of introducing one governance system to communities with vastly differing existing resource governance systems.

At a larger scale, an understanding of past natural resource-use governance can have important impacts on the design and effectiveness of national land use and land tenure policies. As seen in the previous example from the Democratic Republic of Congo, such policies need to factor in historical claims for land, particularly when zoning according to use. One way to increase the applicability of national land use policies is by recognizing historical natural resource governance claims (Côte, in press) and customary institutions (Karambiri, in press).

Until recently postcolonial West and Central African land management and tenure systems have remained largely unmodified, whereby French and English colonial policy generally gave the state centralized authority over all unregistered or common lands (Roe et al. 2009). In the last 20 years, however, many West African countries have moved toward more decentralized systems of land management (Ribot and Larsen 2005), often supported technically and financially by international donor organizations, i.e., UNDP GEF and the World Bank, as described in a case from Senegal (Faye 2015). In Francophone countries the Gestion de Terroirs ( GdT) approach, which emphasizes the creation of locally meaningful socio-spatial units of environmental management, has been widely adopted (Painter et al. 1994). This involves, as a first step, the mapping of village/clan/family boundaries and the clarification of local land tenure. Although the general concept of decentralization is welcomed, the GdT approach, where applied crudely, risks assuming that the concepts or territory and community are homogenous within countries or regions. For example, where GdT was applied in Mali, the nomadic lifestyles of pastoralist herders did not fit within the concept of fixed, easily mapped territories. This resulted in poor representation of pastoralists in terms of land tenure and representation on land-use committees, and a loss of access to crucial grazing and water resources (Painter et al. 1994).

Overall, we have shown that in both case study communities customary hunting governance has undergone significant changes since the precolonial period in response to colonial and early state rules, resulting in more open-access governance systems. The findings further highlight the importance of understanding the effect of past beliefs and governance systems of natural resource use and access, through long-term engagement with communities and through building relationships with community members. Such an understanding can provide crucial insights for identifying drivers and perceptions of environmental change and for determining differences between local and outsider's concepts of resource use. Ultimately, this can help conservation organizations and local people to collaborate in a better way, which can result in more suitable conservation initiatives.

Responses to this article can be read online at: http://www.ecologyandsociety.org/issues/responses. php/8047

\section{Acknowledgments:}

We thank the two anonymous reviewers for their useful comments on the manuscript, and UKAID for covering publication costs. $G W$ : Permission to conduct this research was granted by CENAREST in collaboration with IPHAMETRA. I thank the people of the Djouya Valley for their participation, especially $S$. Touladjan, Kewemie, $L$. Makouka, and M. Nkabi. This research was conducted during thesis work funded by the University College of London's Graduate School Research Scholarship and by an Overseas Research Scholarship Award Scheme. Fieldwork was supported by the Parkes Foundation and the Rufford Foundation. P. Burnham, K. Homewood, J. Fairhead, and P. Laris provided substantial comments that improved earlier versions of the manuscript. Discussions with J.M. Ebouli were also helpful. Patrice Christy kindly advised on colonial laws and their interpretation. LC and JS: Permission to conduct research was granted by Gabon's Ministry of Water, Forests and Environment, and the Mayor of Koulamoutou. We express special thanks to the communities of Dibouka and Kouagna for their participation, hospitality, and kindness. We thank the UK National Environmental Research Council, the British Ecological Society, The Oxford Martin School, the Tropical Agricultural Association, and Green Templeton College of Oxford University for funding this work and the Gabon Program of the Wildlife Conservation Society and the Gabonese Institut de Recherche en Ecologie Tropicale for field support. We further acknowledge CIFOR for contributing toward the publication costs of this article.

\section{LITERATURE CITED}

Adams, W. M. 2007. Thinking like a human: social science and the two cultures problem. Oryx 89(3):275-276.

Agence National des Parcs Nationaux (ANPN). 2013. Programme technique conservation-recherche 2014-2018 pour PN Plateaux Batéké. Agence National des Parcs Nationaux, Libreville, Gabon.

Aicardi de Saint-Paul, M. 1989. Gabon: the development of a nation. Routledge, London, UK.

Badier. 1929. Monographie de la Tribu des Batéké. Bulletin des Recherches Congolaises 10:37-43.

Berkes, F. 2004. Rethinking community-based conservation. Conservation Biology 18:621-630. http://dx.doi.org/10.1111/ j.1523-1739.2004.00077.x

Bernault, F. 1996. Démocraties ambigües en Afrique Centrale: Congo-Brazzaville et Gabon, 1945-1965. Karthala, Paris, France.

Blom, B., T. Sunderland, and D. Murdiyarso. 2010. Getting REDD to work locally: lessons learned from integrated conservation and development projects. Environmental Science and Policy 13:164-172. http://dx.doi.org/10.1016/j.envsci.2010.01.002

Bohannan, P. 1963. 'Land', 'tenure' and 'land-tenure'. Pages 101-115 in D. Biebuyck, editor. African agrarian systems. Oxford University Press for the International Africa Institute, London, UK.

Bond, I., A. Davis, C. Nott, K. Nott, and G. Stuart-Hill. 2006. Community-based natural resource management manual. WWFWorld Wide Fund for Nature Southern African Regional Office, Cape Town, South Africa. 
Bonnafé, P. 1978. Nzo lipfu, le lignage de la mort: la sorcellerie, idéologie de la lutte sociale sur le plateau Koukouya. Recherches Oubanguiennes, Paris, France.

Bout, N. 2006. Suivi écologique des grands mammifères et de l'impact humain: Rapport Final. Projet Plateaux Bateke. Wildlife Conservation Society-Gabon, Libreville, Gabon.

Brink, J. W. 2008. Imagining Head-Smashed-In: aboriginal buffalo hunting on the Northern Plains. Athabasca University Press, Edmonton, Alberta, Canada.

Brosius, J. P. 2006. Common ground between anthropology and conservation biology. Conservation Biology 20(3):683-685. http:// dx.doi.org/10.1111/j.1523-1739.2006.00463.x

Brosius, J. P., A. L. Tsing, and C. Zerner. 2005. Communities and conservation: histories and politics of community-based natural resource management. Altamira Press, Walnut Creek, California, USA.

Buzwani, B., T. Sethogile, J. Arntzen, and F. Potts. 2007. Best practices in Botswana for the management of natural resources by communities. IUCN CBNRM Support Programme, Gaborone, Botswana.

Campbell, L. M. 2005. Overcoming obstacles to interdisciplinary research. Conservation Biology 19:574-577. http://dx.doi. org/10.1111/j.1523-1739.2005.00058.X

Child, B., and G. Barnes. 2010. The conceptual evolution and practice of community-based natural resource management in southern Africa: past, present and future. Environmental Conservation 37:283-295. http://dx.doi.org/10.1017/S0376892910000512

Coad, L. 2007. Bushmeat hunting in Gabon: socio-economics and hunter behaviour. Dissertation. University of Cambridge, Cambridge, and Imperial College London, London, UK.

Coad, L., K. Abernethy, A. Balmford, A. Manica, L. Airy, and E. J. Milner-Gulland. 2010. Distribution and use of income from bushmeat in a rural village, central Gabon. Conservation Biology 24(6):1510-1518. http://dx.doi.org/10.1111/j.1523-1739.2010.01525. $\underline{\mathrm{x}}$

Coad, L., J. Schleicher, E. J. Milner-Gulland, T. R. Marthews, M. Starkey, A. Manica, A. Balmford, W. Mbombe, T. R. Diop Bineni, and K. A. Abernethy. 2013. Social and ecological change over a decade in a village hunting system, Central Gabon. Conservation Biology 27(2):270-280. http://dx.doi.org/10.1111/cobi.12012

Coquery-Vidrovitch, C. 1972. Le Congo au temps des grandes compagnies concessionnaires 1898-1930. Mouton \& Co, Paris, France.

Cordell, J. 1993. Boundaries and bloodlines: tenure of indigenous homelands and protected areas. Pages 61-68 in E. Kemf, editor. The law of the mother: protecting indigenous peoples in protected areas. Sierra Club Books, San Francisco, California, USA.

Côte, M. In press. Autochthony, democratisation and forest: the politics of choice in Burkina Faso. Responsive Forest Governance Initiative Working Paper. J. Murombedzi, J. Ribot, G. Walters, series editors. IUCN, University of Illinois, and the Council for the Development of Social Science Research in Africa, Dakar, Senegal.
Deschamps, H. 1962. Traditions orales et archives au Gabon. Berger-Levrault, Paris, France.

Dressler, W., B. Büschler, M. Schoon, D. Brockington, T. Hayes, C. A. Kull, J. McCarthy, and K. Shrestha. 2010. From hope to crisis and back again? A critical history of the global CBNRM narrative. Environmental Conservation 37:5-15. http://dx.doi. org/10.1017/S0376892910000044

Drury, R., K. Homewood, and S. Randall. 2011. Less is more: the potential of qualitative approaches in conservation research. Animal Conservation 14:18-24. http://dx.doi.org/10.1111/ j.1469-1795.2010.00375.x

Duffy, R. 2006. Non-governmental organisations and governance states: the impact of transnational environmental management networks in Madagascar. Environmental Politics 15:731-749. http://dx.doi.org/10.1080/09644010600937173

Dupré, M.-C. 1994. Raphia monies among the Téké: their origin and control. Pages 39-52 in J. Guyer, editor. Money matters. Instability, values, and social payments in the modern history of West African communities. James Currey, London, UK.

Dupré, M.-C., and B. Pinçon. 1997. Métallurgie et politique en Afrique Centrale: deux milles ans de vestiges sur les Plateaux Batéké Gabon, Congo, Zaire. Editions Kathala, Paris, France.

Dusseljé, E. 1910. Les Tégués de l'Alima, Congo Français. C. de Cauwer, Anvers, Belgium.

Ebouli, J. M. 2001. Les structures de type féodal en Afrique Centrale le cas des Téké: étude des relations de dépendance personnelle et des rapports de production entre "A mfumu” et "Elogo dja Mfumu” (des origines à 1880). Thesis. Université Omar Bongo, Libreville, Gabon.

Etiendem, D. N., L. Hens, and Z. Pereboom. 2011. Traditional knowledge systems and the conservation of Cross River Gorillas: a case study of Bechati, Fossimondi, Besali, Cameroon. Ecology and Society 16(3):22. http://dx.doi.org/10.5751/es-04182-160322

Faye, P. 2015. From recognition to derecognition in Senegal's forests hemming in democratic representation via technical claims. Responsive Forest Governance Initiative Working Paper No. 17. J. Murombedzi, J. Ribot, G. Walters, series editors. IUCN, University of Illinois, and the Council for the Development of Social Science Research in Africa, Dakar, Senegal.

Forbes, W., K. B. Antwi-Boasiako, and B. Dixon. 2014. Some fundamentals of conservation in south and west Africa. Environmental Ethics 36:5-30. http://dx.doi.org/10.5840/ enviroethics20143613

Gami, N. 2003. Mission d'information et d'étude socio-économique dans les villages de la souspréfecture de Lékana (Congo Brazzaville), frontalière du Parc National des Plateaux Bateke (Gabon). Projet Protection des Gorilles, Franceville, Gabon.

Gardinier, D. E., and D. A. Yates. 2006. Historical dictionary of Gabon. Third Edition. Scarecrow, Lanham, Maryland, USA.

Giles-Vernick, T. 2002. Cutting the vines for the past: environmental histories of the Central African Rain Forest. University Press of Virginia, Charlottesville, Virginia, USA. 
Gray, C. J. 2002. Colonial rule and crisis in Equatorial Africa: southern Gabon ca. 1850-1940. University of Rochester Press, Rochester, New York, USA.

Hinz, M. O. 2003. Without chiefs there would be no game: customary law and nature conservation. Out of Africa Publishers, Windhoek, Namibia.

Hymas, O. In press. L'Okoumé, fils du manioc: post-logging in remote rural forest areas of Gabon and its long-term impacts on development and the environment. Thesis, University College London, London, UK.

Jaffré, R. 2003. La mise en valeur de la forêt. Pages 203-274 in P. Christy, R. Jaffré, O. Ntougou, and C. Wilks, editors. La forêt et la filière bois au Gabon. Multipress, Libreville, Gabon.

Jean, S. 1975. Les jachères en Afrique tropicale. Musée de l'Homme, Paris, France.

Karambiri, M. In press. Démocratie locale "en berne” ou péripéties d'un choix institutionnel "réussie" dans la gestion forestière décentralisée au Burkina Faso. Responsive Forest Governance Initiative Working Paper. J. Murombedzi, J. Ribot, G. Walters, series editors. IUCN, University of Illinois, and the Council for the Development of Social Science Research in Africa, Dakar, Senegal.

Kassibo, B. 2002. Decentralised management of renewable natural resources in Mali. Pges 170-179 in C. Toulmin, P. L. Delville, and S. Traoré, editors. The dynamics of resource tenure in West Africa. James Currey, Oxford, UK.

Kinata, C. 2001. Les ethnochefferies dans le Bas-Congo français: collaboration et résistance 1896-1960. L'Harmattan, Paris, France.

Klieman, K. 1997. Hunters and farmers of the Western Equatorial Rainforest: economy and society. C. 3000 B.C. to A.D. 1900. Dissertation. University of California Los Angeles, Los Angeles, California, USA.

Krech, S. 1999. The ecological Indian: myth and history. W.W. Norton, New York, New York, USA.

Laris, P., and D. A. Wardell. 2006. Good, bad or 'necessary evil'? Reinterpreting the colonial burning experiments in the savanna landscapes of West Africa. Geographical Journal 172(4):271-290. http://dx.doi.org/10.1111/j.1475-4959.2006.00215.x

Leach, M., and R. Meanrs. 1996. The lie of the land: challenging received wisdom on the African Environment. James Currey, London, UK.

Leach, M., R. Mearns, and I. Scoones. 1999. Environmental entitlements: dynamics and institutions in community-based natural resource management. World Development 27(2):225-247. http://dx.doi.org/10.1016/S0305-750X(98)00141-7

Le Bomin, S. 2004. Musiques Batéké Mpa Atégé. Editions Sepia, Saint-Maur-des-Fosses, France.

Leopold, A. 2013. A Sand County almanac \& other writings on ecology and conservation. Library of America, New York, New York, USA.
Linton, P. 2008. Classification of Bateke languages. Summer Institute of Linguistic Studies, Grand Forks, North Dakota, USA.

Lowe, P., J. Phillipson, and K. Wilkinson. 2013. Why social scientists should engage with natural scientists. Contemporary Social Science: Journal of the Academy of Social Sciences 8:207-222. http://dx.doi.org/10.1080/21582041.2013.769617

Marks, S. A. 1979. Profile and process: subsistence hunters in a Zambian community. Africa 49:53-67. http://dx.doi.org/10.2307/1159505

Martín-Martín, A., P. Martínez de Anguita, J. V. Pérez, and J. Lanzana. 2011. The role of secret societies in the conservation of sacred forests in Sierra Leone. Bois et Forêts des Tropiques 310(4): 43-55.

Mascia, M. B., J. P. Brosius, T. A. Dobson, B. C. Forbes, L. Horowitz, M. A. McKean, and N. J. Turner. 2003. Conservation and the social sciences. Conservation Biology 17(3):649-650. http://dx.doi.org/10.1046/j.1523-1739.2003.01738.x

Métégué N'nah, N. M. 1981. l'Implantation colonial au Gabon: résistance d'un peuple (1839-1960). 1: les combattants de la première heure. Harmattan, Paris, France.

Mouayini Opou, E. 2005. Le royaume Téké. Harmattan, Paris, France.

Nse Esseng, C. S. 2009. Cartographie participatove des zones communautaires riveraines au Parc National des Plateaux Bateke: phase preliminaire paysage Leconi-Bateke-Lefini. Wildlife Conservation Society, Franceville, Gabon.

Nuesiri E. 2014. The re-emergence of customary authority and its relation with local democratic government. Responsive Forest Governance Initiative Working Paper 6. Council for the Development of Social Science Research in Africa, Dakar, Senegal.

Nze-Nguema, F.-P. 1998. L'Etat au Gabon: De 1929 à 1990 : le partage institutionnel du pouvoir. Harmattan, Paris, France.

Ostrom, E. 2009. A general framework for analyzing sustainability of social-ecological systems. Science 325:419-422. http://dx.doi.org/10.1126/science.1172133

Ostrom, E., and M. Cox. 2010. Moving beyond panaceas: a multitiered diagnostic approach for social-ecological analysis. Environmental Conservation 37:451-463. http://dx.doi.org/10.1017/ $\underline{\mathrm{S} 0376892910000834}$

Oyono, P. R., and F. Ntungila-Nkama. 2015. Zonage des Terres, Conservation des Paysages et Représentation Locale Déboîtée en $R D$ Congo. Council for the Development of Social Science Research in Africa, Dakar, Senegal.

Pagezy, H. 2006. Le contexte magico-religieux de la pêche au lac Tumba: entre le "normal" et l'insolite. Journal des Africanistes 76 (2).

Painter, T., J. Sumberg, and T. Price. 1994. Your "terroir" and my 'action space': implications of differentiation, mobility and diversification for the "Approche Terroir" for Sahelian West Africa. Africa 64(4):447-464. http://dx.doi.org/10.2307/1161368 
Parks, C. C. 1992. Tropical rainforests. Routledge, London, UK. http://dx.doi.org/10.4324/9780203413463

Peterson, R. B., D. Russell, P. West, and J. P. Brosius. 2010. Seeing (and doing) conservation through cultural lenses. Environmental Management 45:5-18. http://dx.doi.org/10.1007/s00267-008-9135-1

Pierotti, R., and D. Wildcat. 2000. Traditional ecological knowledge: the third alternative (commentary). Ecological Applications 10:1333-1340. http://dx.doi.org/10.1890/1051-0761 (2000)010[1333:TEKTTA]2.0.CO;2

Pourtier, R. 1989b. Le Gabon Tome 1: Espace, histoire, société. Harmattan, Paris, France.

Pourtier, R. 1989a. Le Gabon Tome 2: Etat et développement. Harmattan, Paris, France.

Reed, M. C., and J. F. Barnes. 2003. Culture, ecology, and politics in Gabon's rainforest. Edwin Mellen Press, Lewiston, New York, USA.

République Gabonaise. 1963. Loi no. 14/63 du mai 1963: fixant la composition du Domaine de l'Etat et les règles qui en déterminent les modes de gestion et d'aliénation. République Gabonaise, Liberville, Gabon.

Ribot, J. C., and A. M. Larson, editors. 2005. Democratic decentralisation through a natural resources lens. Routledge, London, UK.

Roe, D., F. Nelson, and C. G. Sandbrook. 2009. Community management of natural resources in Africa: impacts, experiences and future directions. Institute for Environment and Development, London, UK.

Sasaoka, M., and Y. Laumonier. 2012. Suitability of local resource management practices based on supernatural enforcement mechanisms in the local social-cultural context. Ecology and Society 17(4):6. http://dx.doi.org/10.5751/es-05124-170406

Schleicher, J. 2010. The sustainability of bushmeat hunting in two villages in Central Gabon. Thesis. University of Oxford, Oxford, UK.

Schultz, P. W. 2011. Conservation means behaviour. Conservation Biology 25:1080-1083. http://dx.doi.org/10.1111/j.1523-1739.2011.01766. $\underline{\mathrm{x}}$

Shackleton, C. M., T. J. Willis, K. Brown, and N. V. C. Polunin. 2010. Reflecting on the next generation of models for communitybased natural resources management. Environmental Conservation 37:1-4. http://dx.doi.org/10.1017/s0376892910000366

Sola, P. 2005. The community resource management plan: a tool for integrating IKS into natural resource management. Ethnobotany Research \& Applications 3:143-153.

Soulé, M. E. 1985. What is conservation biology? BioScience 35:727-734. http://dx.doi.org/10.2307/1310054

Stern, M. J. 2010. Payoffs versus process: expanding the paradigm for park/people studies beyond economic rationality. Journal of Sustainable Forestry 29:2-4. http://dx.doi.org/10.1080/10549810903547809

Toulmin, C., P. L. Delville, and S. Traoré. 2002. The dynamics of resource tenure in West Africa. IIED and James Currey, Oxford, UK.
United Nations Department of Economic and Social Affairs/ Population Division. 2005. World urbanization prospects: the 2005 revision. United Nations, New York, New York, USA.

U.S. Forest Service. 2008. U.S. Forest Service guide to land-use planning for community based natural resource management macro-zones in Central Africa. U.S. Forest Service, Washington, D.C., USA.

Van der Veen, L. J. 1991. Etude comparée des parlers du groupe Okani. Dissertation. Université Lumière, Lyon, France.

Van der Veen, L. J. 2003. The B30 language group. Pages 370-391 in G. Philippson and D. Nurse, editors. The Bantu Languages. London, Routledge, London, UK.

Vansina, J. 1973. The Tio Kingdom of the Middle Congo 1880-1892. Oxford University Press, London, UK.

Vansina, J. 1990. Paths in the rainforest: toward a history of political tradition in Equatorial Africa. James Currey, London, UK.

Walters, G. 2010. The land chief's embers: ethnobotany of Bateke fire regimes, savanna vegetation and resource use in Gabon. University College of London, London, UK.

Walters, G. 2012. Changing customary fire regimes and vegetation structure in Gabon's Bateke Plateaux. Human Ecology 40:943-955. http://dx.doi.org/10.1007/s10745-012-9536-x

Walters, G. In press. Changing fire governance in Gabon's Plateaux Bateke savanna landscape. Conservation and Society.

Walters, G., S. Touladjan, and L. Makouka. 2014. Integrating cultural and conservation contexts of hunting: the case of the Plateaux Bateke savannas of Gabon. African Study Monographs 35:99-128.

Waylen, K. A., A. Fischer, P. J. K. McGowan, S. J. Thirgood, and E. J. Milner-Gulland. 2010. Effect of local cultural context on the success of community-based conservation interventions. Conservation Biology 24:1119-1129. http://dx.doi.org/10.1111/ j.1523-1739.2010.01446.X

West, P., and D. Brockington. 2006. An anthropological perspective on some unexpected consequences of protected areas. Conservation Biology 20:609-616. http://dx.doi.org/10.1111/ j.1523-1739.2006.00432.x

Wunder, S. 2003. When the Dutch disease met the French connection: oil, macroeconomics and forests in Gabon. Center for International Forestry Research, Bogor, Indonesia.

Yanggen, D., K. Angu, and N. Tchamou, editors. 2010. Landscape-scale conservation in the Congo Basin: lessons learned from the Central African Regional Program for the Environment ( $C A R P E)$. International Union for the Conservation of Nature, Gland, Switzerland.

Yates D. A. 1998. The rentier state in Africa. Africa World Press, Trenton, New Jersey, USA. 